\title{
Tudomány
}

Szabó Géza

\section{A nő ábrázolása a Nagyszentmiklósi kincs 2. korsóján - Értelmezési lehetőségek a kaukázusi régészeti és néprajzi párhuzamok, valamint az újabb kutatási eredmények alapján}

\begin{abstract}
A honfoglalás kori régészeti leletek között egészen kivételesnek számít a nő ábrázolása. Mindöszsze a Nagyszentmiklósi kincs 2. és 7. korsóinak oldalán látható nő egy ragadozó madár karmai között. Az újabb kutatási eredmények alapján minden korábbinál hangsúlyosabban merül fel az a lehetőség, hogy a Nagyszentmiklósi kincs 2. korsóján látható nő ábrázolása kivételes személyt és pillanatot, az Árpád-ház ősanyját (Emesét?) jeleníti meg, az eredetmondának megfelelően a sassal való násza közben.
\end{abstract}

A honfoglalás kori régészeti leletek között noha gyakran és változatos formában jelennek meg a női princípiumra vonatkozó utalások, ${ }^{1}$ mégis egészen kivételesnek számít magának a nőnek az ábrázolása. Mindössze egyetlen leletegyüttesben, a Nagyszenmiklósi kincs 2. és 7. korsóinak oldalán látható nő egy ragadozó madár karmai között. Azonban a 23 aranyedényből álló, közel 10 kg súlyú kincslelet 1799-es megtalálása óta a kutatás még a legalapvetőbb kérdésekben - a készítés és használat idejét, korát, a történeti hátteret és az ábrázolások értelmezésében - sem jutott egységes álláspontra. $A$ Nagyszentmiklósi kincs keltezéséről és népességéről hagyományosan három elképzelés merült fel:

a) 7-8. századi késő avar ötvösremek, ${ }^{2}$

b) 9. századi bolgár aranylelet, ${ }^{3}$

c) honfoglalás kori magyar, 10-11. századi fejedelmi készlet. ${ }^{4}$

László Gyula a kezdetektől meglévő, látszólag nehezen feloldható véleménykülönbségeket azzal a megjegyzéssel hidalta át, hogy a késői avar fémművesség és a honfoglalás kori magyarok poncoltdomborított ötvössége, valamint a bolgár fémmüvesség felé mutató szoros kapcsolatok alapján az edények nem egyik vagy másik nép környezetében készültek, hanem mindhároméban. ${ }^{5}$ 


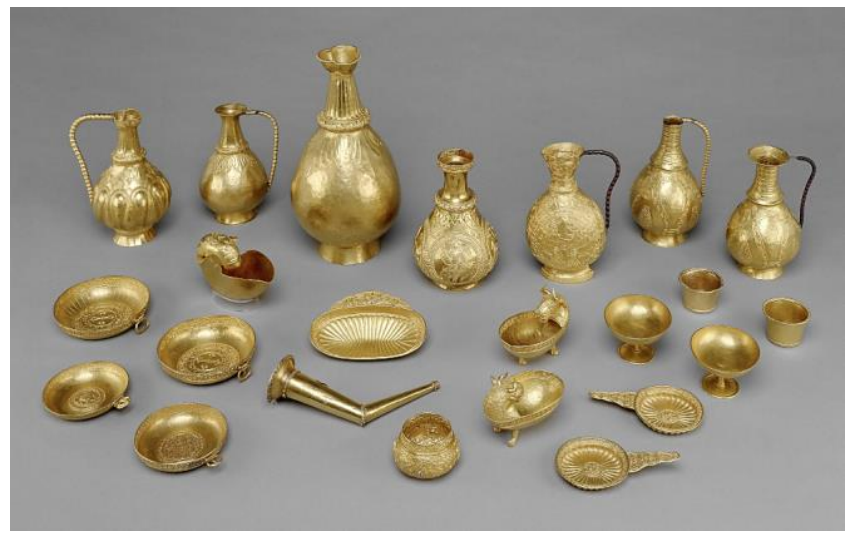

A Nagyszentmiklósi kincs

(Fotó: Kunsthistorisches Museum Wien)

Az utóbbi évek újabb kutatási eredményei is sorra azt erősítik meg, hogy a Nagyszentmiklósi kincs tárgyai, azok kapcsolatrendszere egyre kevésbé szűkíthető le egyetlen időszakra, kultúrára, népre. Az ezredforduló után Budapesten $A$ nagyszentmiklósi kincs - Az avarok aranya ${ }^{6}$ című kiálítás egyértelmú álláspontja, a 7-8. századi keltezés, a késő avar kori ötvösremekként való meghatározás ${ }^{7}$ ellen egyre több érv szól. A hazai kutatásban különösen a rovásfeliratok tanulmányozása, ${ }^{8}$ a nemzetközi porondon pedig a leletek alapos archaeometriai vizsgálata9 és a többnyire annak folyamatához, eredményeihez szorosan kapcsolódó tanulmányok hoztak teljesen új, esetenként meglepő eredményeket. ${ }^{10} \mathrm{~A}$ továbbiakban számolni kell azzal, hogy a különböző időszakokban készített, egyenként is eltérő módon formálódó, részben utólag felvitt díszítések adják a széles körből (keleti, bizánci, bolgár, alpi területekről akár ajándékként, rablással, a magyar kalandozások során kolostorok kifosztásával stb.) összegyűjtött Nagyszentmiklósi kincsnek sehol másutt nem tapasztalható és megismételhetetlen egyediségét, az egyes tárgyaknak, elemeknek az Uraltól, Irántól, Kaukázustól kezdve Bizáncon, Itálián, az Alpokon át Angliáig követhető párhuzamai ellenére is. ${ }^{11}$

Az újabb adatok és megfigyelések arra is rávilágítanak, hogy visszakanyarodva a magyar kutatásban László Gyula, Vékony Gábor által már korábban feltételezett keltezéséhez, ${ }^{12}$ megalapozottan lehet számolni a kincs 9. századnál nem korábbi elrejtésével, írás- és nyelvtörténeti érvek alapján ${ }^{13}$ az aranyedények akár 10-11. századi használatával is. Így pedig a 2. és 7. korsó oldalán látható női ábrázolás joggal sorolható a honfoglalás kor emlékei közé. Azonban ebből még nem következik az, hogy ezek az ábrázolások nemcsak a korszak, hanem a közvetlenül a honfoglalóink ízlését, gondolatvilágát is tükrözik. A 6. korsón olvasható négynyelvű szövegben szereplő, valamint az alán dan „víz” szó azonban ismételten felhívja a figyelmet a korabeli női viseletünk jellegzetes kellékei, az áttört hajfonatkorongok esetében Fodor István által kimutatott, a 8-9. századi észak-kaukázusi alán és a szaltovói múveltséggel való szoros kapcsolatokra. ${ }^{14} \mathrm{Az}$ iráni nyelú és kultúrájú népek közé tartozó alánok kaukázusi utódainál, az oszéteknél a bronzkortól szinte változatlan formában megőrzött szokások mutattak rá arra, hogy számos esetben egy olyan kulturális kontinuitás figyelhető meg, amely évezredeken át szinte változatlan formában rögzítette a társadalmi rend, a hitvilág jelképeit. Az adott földrajzi térségben hosszú időn át hasonló dinamikával zajó, a történeti folyamatokat is tükröző ábrázolásokban megfogalmazott, évezredeken át kicsiszolódott, finomodott üzenetek egészen apró részletei is széles körben egyértelműen értelmezhető jelentéseket hordoztak és hordoznak 
a mai napig. ${ }^{15}$ Ez a környezet egy régész számára egyben egy időutazás, egy új világ, egy teljesen más gondolkodásmód megismerésével ${ }^{16}$ egyben lehetőséget ad a régi dolgaink más szemléletű megközelítésére, adott esetben a Nagyszentmiklósi kincs 2. és 7. korsóján látható nőalakok kulturális hátterének, lehetséges jelentésének, üzenetének jobb megvilágításához, pontosításához is.

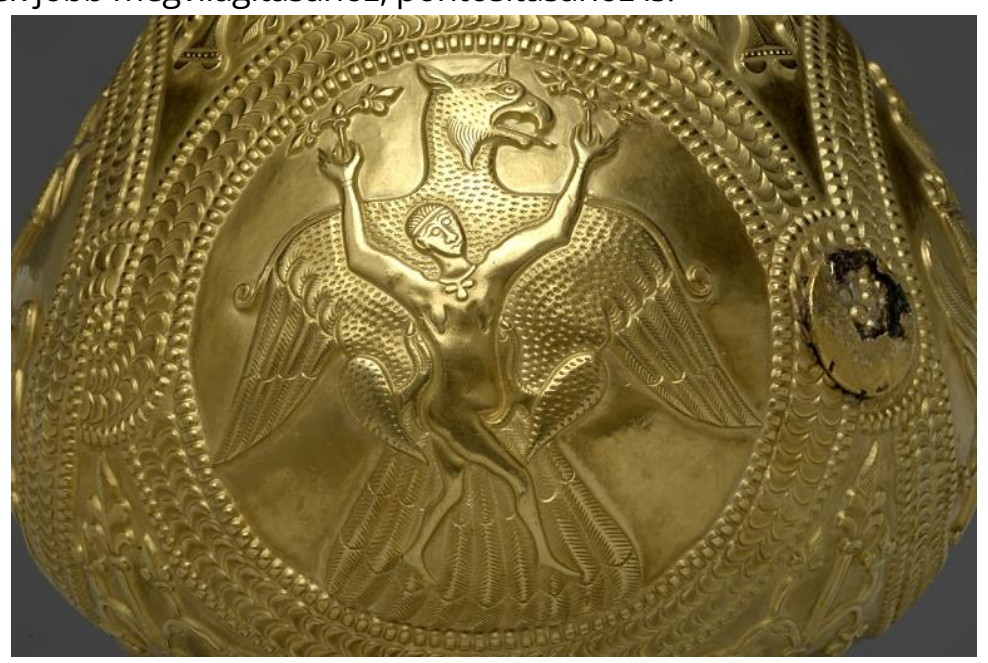

Az ősanya és a sas nászának jelenete a 2. korsón

(Fotó: Kunsthistorisches Museum Wien)

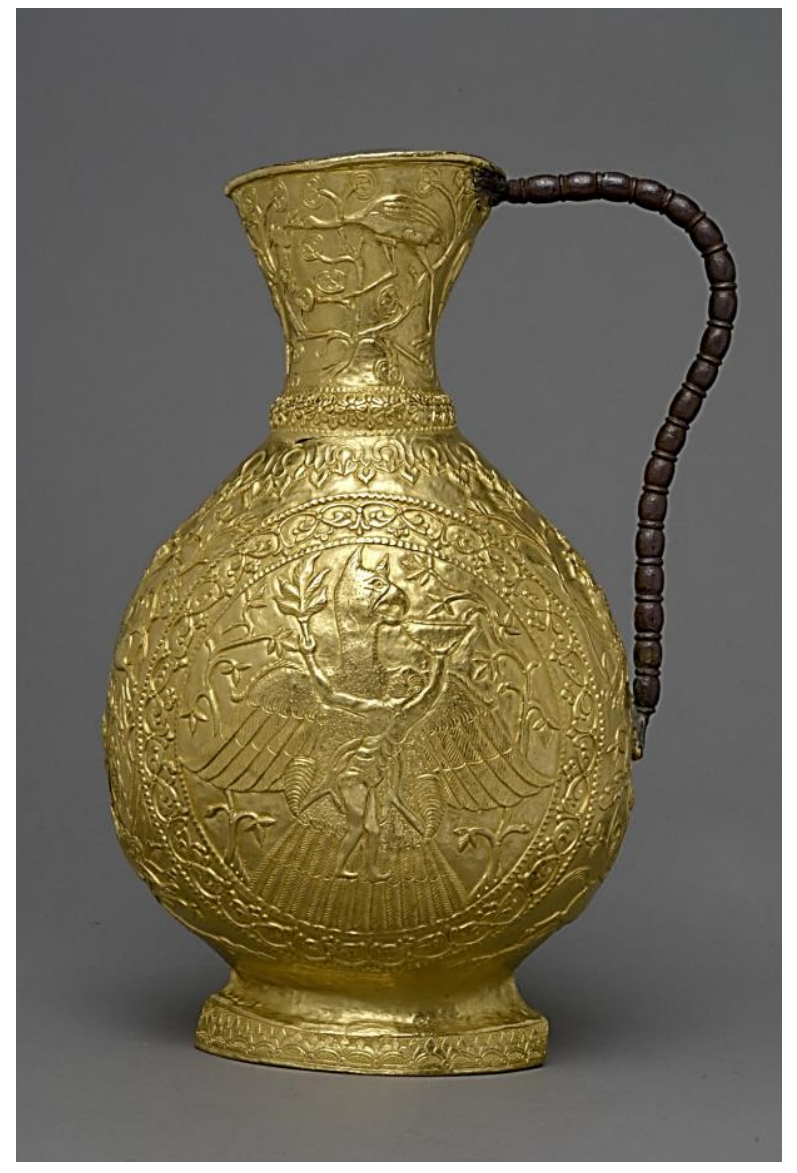

A 7. korsó

(Fotó: Kunsthistorisches Museum Wien) 
Hampel József a 2. és a 7. korsó medallionjának leírásánál is a ragadozó madár karmai között még mindkét oldalon egyértelműen női ábrázolást említ. ${ }^{17}$ Azonban a későbbiekben a bolgár Nikola Mavrodinov már úgy értelmezte a jeleneteket, hogy a 2. korsón egy nő palmettával eteti a madarat, a 7. korsó oldalán pedig egy izmos hasú férfi itatja egy tálból a ragadozót. ${ }^{18} \mathrm{Az}$ ábrázolások értelmezéséhez széles körből hozott antik példákat is bevont vizsgálatának körébe, a 7. korsó medallionja kapcsán tanulmányozta például az indiai mitológiából Visnu isten jármúvét, a sasfejü, embertestű lényt, Garuda alakját is, ugyanakkor a jelenetet a Zeusz által sas képében elrabolt, Ganümédészhez kötötte. ${ }^{19}$ Értékelésének ezt a részét aztán többen lényegében kritika nélkül átvették még az utóbbi évtizedekben is. ${ }^{20}$

Újabban Nikolay Markov a Nagyszentmiklósi kincs két korsóján látható ábrázolások értelmezésére az iráni kultúrkör mítoszain belül talált meggyőzően logikus magyarázatokat. ${ }^{21} \mathrm{~A}$ bolgár szerző ugyan együtt beszélt a 2. és 7. korsóról, azonban valójában inkább csak a 7. korsó ábrázolásait elemezte részletesebben. Ő élesen bírálta és elutasította mind a tárgyak Kárpát-medencei avar készítését, mind pedig a dunai proto-bulgár eredetet, valamint a Ganümédész elrablásáról szóló mítosszal való összekapcsolást is. ${ }^{22}$ A 2. korsó esetében lényegében az Avesztából és a zoroasztriánus vallásokból ismert Anahita, a vizek ősi indoiráni istennőjével kapcsolatos, Kamilla Vasziljevna Trever által már 1937-ben leírt ${ }^{23}$ magyarázathoz kanyarodott vissza. A korsókon látható személyek közül szerinte a lángoló koronás fő Takhmurasz, aki a gonosz Ahrimán legyőzése után azon lovagolt („vadászjelenet”), a páncélos vitéz („győztes fejedelem”) az Uladot foglyul ejtő Rusztem, aki Raksh lovának nyerge mögé Arshlang fejét akasztotta. ${ }^{24}$ Ugyancsak a perzsa mítoszokat őrző Sáhnáme sorait idézi Szám sah kitagadott fia, Zál kapcsán is, akit száműzetésében az Alburz hegység sziklái között egy nőstény oroszlán szoptatott, amíg Szimurg el nem ragadta táplálékul a fiókáinak, akik azonban nem ették meg, hanem vérrel itatták, s így hatalmas vitéz lett belőle. Ebben az összefüggésben szerinte értelmezhetők az olyan részletek is, mint az emberi test meztelensége, a madár felé nyújtott edényben a szóma (haoma), az isteni halhatatlanság itala és a démonok, valamint a boszorkányok legyőzését segítő barszuma ág is. ${ }^{25}$ (Azonban meg kell jegyezni, ez a magyarázat azt is feltételezi, hogy a 7. edény mindkét oldalán látható emberi lény neme férfi.) A 7. korsó nyakán lévő növényt ${ }^{26}$ az életet adó, gyógyító, hatalmas Gaokerena fával azonosította, amelynek gyümölcse a halhatatlanság elixírjét tartalmazta. Ez a fontos jelkép továbbélt a kereszténységben és az iszlámban is. A fa elpusztítására a gonosz békaként a gyökerek közé fészkelt, a korsó nyakán ez magyarázná a béka ábrázolását és aránytalanul nagy méretét, a rá vadászó gém pedig a rossz felett győzedelmeskedő jó megtestesítője. ${ }^{27} \mathrm{~A}$ kutató szerint a korsók ábrázolásain a perzsa mítoszokban, a zoroasztriánus jelképrendszerben jól követhető jegyek alapján a túzimádást valló, ősi iráni népek kulturális hagyományai tükröződnek. Ugyanakkor a 2. korsón látható szarvas és griff jelenetének nem találta konkrét párhuzamát a zoroasztriánus jelképek között, ezért csak általánosságban kötötte a jó és a gonosz harcának gondolatához. ${ }^{28}$ Más megközelítésben ez azt is jelenti, hogy amíg nézőpontja szerint a 7. korsó szinte minden apró részletig magyarázható az Avesztából vagy a Sahnáméból a késő szaszanida fémművesség jelképeivel, addig a 2. korsón az egyik jelenet egyáltalán nem kapcsolható oda. Érdemes a két aranyedényen lévő ragadozó madár jelenetét részleteiben külön is összehasonlítani. Teljesen hasonló a sas minden mozdulata, még a felső káváján karéjos csőr részlete is. Ugyancsak azonos a feltekintő, feltett kezeit széttáró, csípőjében félig elforduló, emberi lény is. (Annak jelzésére használom az emberi lény kifejezést, hogy az esetleges eltérések szempontjából most a nemiség kérdése lényegtelen, annak vizsgálata majd a következő lépés lesz.) A sas felé felnyújtott kezekben a 2. korsón mindkét oldalon egy leveles, nóduszos indájú ág van, hasonló növényből, mint amilyen a korsó nyakán is látható. A 7. korsón lévő személy pedig mindkét oldalon az edény füle felé 
forduló madár csőréhez az egyik kezében phialét tart, a másikban meg egy dúslevelű ágat. Az ábrázolásokon az azonos szerkezet megőrzésére a két oldalon a tárgyakat tartó jobb-bal kezet felcserélték. Az ág levélzete azonos a többi jelenetet is körbeölelő növényével, de nem hasonlítható a korsó nyakán látható, feltehetően Gaokerena fáéhoz. ${ }^{29} \mathrm{~A}$ két ábrázolás között alig van különbség, azonban a 7. korsón a madár csőréhez tartott phiale a másikhoz képest mindenképpen már egy további elemet jelent. Az is világosan látható, hogy a látszólag hasonló jelenet ellenére a kompozíció teljessége érdekében a phiale helyett is magasba tartott nóduszos indájú ág ugyanakkor már egy olyan különbséget is takar, amely már egy másik, nemcsak általánosságban, hanem pontosan megfogalmazott, a helyi közösség számára jól és egyértelműen érthető üzenetet közvetített. Ebből a szempontból viszont már lényeges elem az emberi lények neme is. A 2. korsónál a mellek ábrázolása alapján ez nem kérdéses. A 7. korsónál elsősorban a redőzött has ábrázolása alapján merült fel, hogy az esetleg férfira utalna. Érdemes azonban megnézni például Mavrodinovnak a nemi meghatározáshoz és a Ganümüdésszel való azonosításhoz kapcsolódó ábráit, amelyeken jól látható, hogy a korsón lefelé lógó redők helyett az izmos hason az izomkötegek jellemzően felfelé ívelnek ${ }^{30}$ - erről egyébként a természetben is bárki meggyőződhet. Mindez arra mutat, hogy a korsókon a sas ölében tartott személy mindegyik esetben nő volt, és a jelenet értelmezésének lehetőségeit is ebben az irányban kell és érdemes is keresni. Természetesen ez azt is jelenti, hogy a Nikolay Markov által felvetett lehetőségek közül a korsókon látható sast sem lehet a Zált elragadó Szimurggal azonosítani, ${ }^{31}$ sokkal valószínúbb a vizek ősi indoiráni istennőjével, Anahitával kapcsolatos feltételezése a 7. korsó kapcsán is. ${ }^{32}$ Ez utóbbit támasztja alá az is, hogy a mezopotámiai szövegben a mindenható Innin éneke szerint

„A madárnak, bizony, megadom, ami méltó hozzá, Anzunak, bizony, megadom, ami méltó hozzá: asszonyát kedvesen megölelem, Anzu asszonyát, Anzu gyermekét dús lakomához ültetem. S mert hát An az árpaföldek úrnőjét a hegyvidékről idehozta..." ${ }^{\prime 33}$

Az ég urát jelképező sas és az árpaföldek úrnőjének összekapcsolódása jelezheti a 7. korsón a madár csőréhez tartott phiale lehetséges tartalmát, az áldozatok bemutatásánál bőven folyó szent sört és a főzéséhez használt nóduszos indájú növényt, a komlót is. ${ }^{34}$

A korsókon látható ábrázolások irodalmának áttekintése mellett vizsgáljuk meg azt a környezetet is, amelybe a 6. korsón lévő alán nyelvű felirat ${ }^{35}$ és a honfoglalás kori női viselet legszebb elemei, a hajfonatkorongok párhuzamai ${ }^{36}$ egyaránt mutatnak: a Kaukázusban lakó, alán utódok, a hagyományaikat, szokásaikat a bronzkor óta szívósan őrző oszétek világát is. A kaukázusi hagyományokon felnevelkedett ember szempontjából például a 2. és 7. korsón látható ragadozó madár értelmezéséhez álljon itt az a történet, amely jól tükrözi, hogy mit tartanak a sasról még ma is az oszét nők, és amely meggyőződésem szerint a Nagyszentmiklósi kincs tárgyai mellett számos honfoglalás kori leletünk üzenetének megértéséhez is hozzásegít bennünket. Róza Tandelova és Galina Dzsidzsojeva osztotta meg velem az ironoknak és digoroknak ${ }^{37}$ azt a természetismeretüket tükröző történetét, ahogyan a kaukázusi hegyek nagy testű ragadozó madara, a szirti sas egy életre társat választ magának. Amikor eljön a párválasztás ideje, akkor a tojó letör egy gallyat egy fáról vagy bokorról, a csőrébe veszi, és nagy magasságba emelkedik vele, majd körözni kezd. A hímek odagyűlnek és körbeveszik a tojót, aki leejti az ágat, és figyeli, hogy melyik sas kapja el és hozza fel neki újból és újból, majd adja neki vissza óvatosan a csőrébe. Ezt sokszor megismétlik, amíg a tojó teljesen biztos lehet abban, hogy a hím a ledobott ágat elkapja és vissza tudja vinni, a 
nászukra csak azután kerülhet sor. A nagy testú szirti sas fiókái sokáig tehetetlenek, csak lassan érnek meg a repülésre, ezért a pár fészküket magas, megközelíthetetlen sziklafalakra építi. A nagyméretü, ágakból, gallyakból rakott fészket saját tollazatukból kitépett pihékkel bélelik a hideg ellen. A kiköltött tojásokból előbújó esetlen fiókákat a puha, meleg fészekben a szülők a testükkel védik, takargatják az esőtől, a tűző naptól, vizet, ételt visznek nekik egészen addig, amíg meg nem erősödnek, ki nem nő a szárny- és farktolluk is. Akkor a hím a fészek szélére ül és szárnyaival verni, csépelni kezdi azt, hogy az összes toll kiessen belőle és csak a kemény ágkeret maradjon meg. A fiókák a kényelmetlenné vált fészekben megszeppenve figyelik, hogy anyjuk ezúttal a fészektől pár méterre leül az etetésükre hozott hallal, és elkezdi enni a zsákmányt. Az egyre éhesebb és türelmetlenebb fiókák kiabálnak, rikácsolnak, követelik az ételt, nem értik, mi történik, miért olyan kényelmetlen és huzatos a fészek, miért nem kapják a megszokott módon a csőrükbe az húsdarabokat. Korábban még soha nem végzett dolgot kell tenniük: ahhoz, hogy anyjukhoz és a táplálékhoz jussanak, kénytelenek kiugrani a fészekből. Nehéz, erőtlen testük még ügyetlen ahhoz, hogy elérjenek az anyáig, így a magas sziklafalról a mélybe zuhannak. Az apjuk azonban utánuk repül, és zuhanás közben elkapja őket, fiókáit visszaviszi a fészekbe. Továbbra sem kapnak enni, ezért kezdődik minden elölről, újból és újból, amíg egyszer csak kitárt szárnyukon siklani kezdenek, és többé már nem kőként zuhannak, hanem repülnek, a táplálékkal egyre messzebb és messzebb leülő anyjukhoz tudnak menni, és aztán megismerik a távoli halászó helyeket is, készülnek az önálló életre.

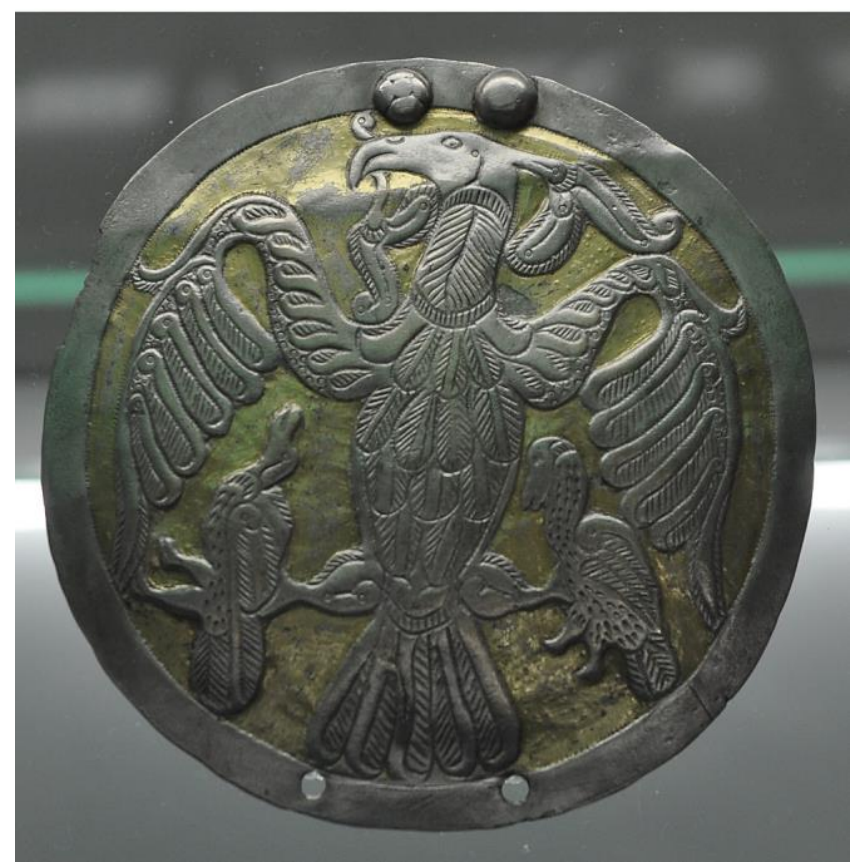

A rakamazi hajfonatkorong

(Fotó: Szabó Géza)

A nem véletlenül a nők körében népszerü, reális elemekre épülő párválasztási tantörténetnek a régészet oldaláról több szempontból is szintén nagyon fontos üzenete van. Ahogyan Nikolay Markov meggyőzően logikus magyarázatokat talált a Nagyszentmiklósi kincs 7. korsóján látható ábrázolások értelmezésére az iráni kultúrkör mítoszain belül, a kaukázusi szokások, hagyományok értelmében a fenti elbeszélés alapján is a konkrét esetben végképp elvethető a görög kultúrkörhöz kötődő Ganümédész-legenda felőli megközelítés. ${ }^{38}$ Továbbá a 2. korsó esetében a sas és az ölében ábrázolt nő a kaukázusi sasok viselkedése alapján teljes egészében értelmezhető a párválasztás, nász jeleneteként - amit két dolog is megerősít: a 
sas csőre felé nyújtott nóduszos ág, valamint a rakamazi hajfonatkorong hasonló jelenete is. ${ }^{39}$ Ott azonban még direktebb és realisztikusabb, a kaukázusi tantörténetet még jobban tükröző a jelenet megfogalmazása: rakamazi korongon a sas a csőrében nóduszos, palmetta leveles indát tart, a karmai között pedig két fiókáját fogja. A 2. és 7. korsón félrevezető módon általánosan „égberagadási jelenet”-nek nevezett ábrázolást ha tartalmi elemeire és az ismertetett természeti-néprajzi párhuzamokra is figyelemmel vagyunk, akkor teljesen világos, hogy nászjelenetről, ${ }^{40}$ a termékenységről van szó mindkét esetben, amelynek célja az utódok nemzése. Erre egyik jó és legteljesebb példa a permi, Bolsaja Anyikova lelőhelyen talált, 6-7. századra keltezhető, feltehetően kelet-iráni készítésű tál, ahol a sas és a nő mellett a két "vadász", azaz utód is látható. ${ }^{41} \mathrm{~A}$ gyökereiben a bronzkorig visszanyúló és széles körben elterjedt jelenet változatain jól látható, hogy az ábrázolásokon a sas nemcsak nőt ölelhet át karmaival, hanem agancsos szarvastehenet, az ősanyát jelképező csodaszarvast is foghat, mint például az altaji szkíta aranyleleten ${ }^{42}$ vagy a szaszanida edényeken. ${ }^{43} \mathrm{~A}$ termékenység ábrázolásának ez a módja szervesen kapcsolja a kincs reliefjeit a kaukázusi és a sztyeppei, szaszanida leletekhez ugyanúgy, mint a honfoglalás kori viseleti tárgyakhoz. Ebbe a sorba tartozik a 8. csésze utólag ráforrasztott ${ }^{44}$ fülén látható nagymacska és "szent fa” ókori eredetű, bőséget, termékenységet jelentő ábrázolása, ${ }^{45}$ amely szintén közel áll a honfoglalók női hajfonatkorongjain látható hasonló jelenetek képi és tartalmi világához.

A Nagyszentmiklósi kincsleletben a 2. és 7. korsónál a fenék egyaránt enyhén homorú kiképzése eltér a másik öt tárgy gyürűszerüen kialakított aljától. ${ }^{46} \mathrm{~A}$ két korsó díszítése között a hasonló témájú ábrázolások ellenére is jól megfigyelhető formai eltérések vannak. Ilyen például a 7. korsó esetében az értelmezés szerint két fa (szőlő) közötti jelenet ${ }^{47}$ is, ahol hiányoznak a szaszanida múvészetben gyakori szőlőfürtös indákra, hálókra utaló részletek. ${ }^{48} \mathrm{Az}$ indás növényeknek automatikusan a szőlővel, borral való összekapcsolása a kutatásban egy általános toposz, amely teljesen figyelmen kívül hagyja, hogy az áldozati ital - és így az ábrázolt növény is - kulturálisan meghatározott, az egyes népek életmódjára, hagyományaira jellemző, évezredeken át jól követhető szál. ${ }^{49}$ Pedig esetünkben is fontos, hogy miért lehet a Nagyszentmiklósi kincs számos edényén a sajátos szerkesztésű, a honfoglalás kori leleteinkéhez hasonló palmetta, a felirata szerint egy időben biztosan a sör tárolására szolgáló palack (6. korsó) mellett a 2. korsón is szőlőfürtök nélküli, nóduszos indájú növényre, a komlóra mutató ábrázolás. $A z$, hogy a nő a párzásra utaló ágként éppen komlóindát nyújt a sasnak, következhet egyszerűen a kompozícióból is (éppen ez van mellette), ám valószínűbb a jóval bővebb jelentés a növény égi eredetére, a szent sörre való utalás. A rakamazi és a jánosszállási korongok ragadozó madarának szájában lévő indadarab ugyancsak egyértelműen utal a komlózott sört feltaláló oszét ősanya, Satana égi növényére valamint az azzal készült szent áldozati italra is - és mint a sas párválasztása mutatja, a nászra. Mindezek a formai hasonlóságok mellett olyan szoros tartalmi, jelentésbeli egyezéseket mutatnak a honfoglalás kori ötvöstárgyaink ábrázolásai és a Nagyszentmiklósi kincs egyes elemei között, amelyek egyértelművé teszik a kettő közötti kapcsolatot. Egyúttal pedig fel is hívják a figyelmet arra a mára szinte teljesen feledésbe merült tényre is, hogy a honfoglalóknak a sör fontos itala volt, olyannyira, hogy Európában egyedülálló módon még az Árpád-korban is törvények biztosították a jobbágyok jogát az árpaföldjük múvelésére, a sör szabad főzésére. A sörfőzés általánosságát jól mutatja az a szokás, amely szerint Szent Márton napján a pannonhalmi apátság kiterjedt birtokainak minden falva egy vödör sört ajándékozott a kolostornak. Sőt, Budán még a 17. században is sört fözött és mért minden telkes polgár, a főzés aranyos szabadságuk jelképe volt. ${ }^{50}$ 
A 2. és 7. korsónak a kincslelet korsóin belül is legszorosabb, a késő szaszanida fémművesség és kulturális hagyományok felé mutató szálai (készítéstechnika, ábrázolások fő vonásai), ugyanakkor a részletekben egyértelműen megfigyelhető eltérések ugyanannak a folyamatnak a késői tükröződései, amelyet már a Koban-kultúra közvetítő szerepénél is megfigyeltünk. ${ }^{51} \mathrm{~A}$ látszólag hasonló jelentésű ábrázolások részletein, a 2. korsón a Gaokerena fát a késő szaszanida jelképrendszert pontosan ismerő és nemcsak másolására, de megújítására, átfogalmazására (minőségi meghaladására) is képes ötvös a helyi hagyományok alapján a komló indáival helyettesítette. ${ }^{52} \mathrm{~A} 6$. korsó alán nyelvű rovásfelirata azt erősíti, hogy az iráni népcsoportokon belül az oszétek Nart-eposzában ${ }^{53}$ is látható jelentősége, a szent sör főzése és védő, bajelhárító szerepe miatt a Kaukázus környékén lehetett az a szűkebb, de határozott helyi jegyekkel rendelkező hagyományrendszer, amelynek jellegzetességei a Nagyszentmiklósi kincs 2. korsóján látható nőalak jelenetének egyedi megfogalmazását adták. Ugyanebben a körben jól értelmezhető a honfoglalás kori fémmúvességünk számos kedvelt díszítőeleme is, mint például a rakamazi hajfonatkorongpáron a csőrében nóduszos indát, karmaiban fiókáit tartó sas képe, vagy a tarsolylemezeken, szablyákon látható hálós szerkesztésű, jegyeiben a komlóra, jelentésében a védő, bajelhárító szerepre utaló indadíszek is. ${ }^{54}$ A Nagyszentmiklósi kincs 2. korsóján látható nőalak jelenete a természeti előképek alapján arra is felhívja a figyelmet, hogy - a kutatásban általánosan elterjedt véleményekkel szemben - a sokkal gondosabb kivitelezésű 2 . korsó nem lehet előképe a hetediknek, ${ }^{55}$ csak fordítva: a szaszanida hagyományok elemeit szélesebb körben tartalmazó 7. korsó lehetett a minta a 2. jelenetsora elkészítéséhez. ${ }^{56}$ Az alaptestben és a díszítésben is szemmel láthatóan is eltérő stílusú 2. és 7. számú kancsó hátterének kialakításához teljesen hasonló, könnycsepp alakú poncok használta ${ }^{57}$ önmagában is arra mutat, hogy a két tárgy egy időben volt az ötvös kezében, ami lehetővé tette az előkép használatát. Az újabb archaeometriai vizsgálatok eredményei arra mutatnak, hogy az ötvös legalább a leletek egy részénél a korábban készített aranyedények felületét dolgozta át, egységesítette az utólagos díszítésekkel. Ebbe a sorba tartozik a 2. korsó is, amelyen a nőalakját a honfoglalás kori leletek között szokatlan kivételként a maga teljességében és ráadásul meztelenül ábrázolta. A korabeli viseletben a nőiségre utaló, finoman, de mégis pontosan és mindenki által egyértelműen érthető módon megfogalmazott jelképek ${ }^{58}$ mellett ez a feltűnő és az általánostól való jelentős eltérés mindenképpen magyarázatra szorul. Nyilvánvalóan az ötvös a nagy értékű edényeket a társadalmi elit felső rétegébe tartozó megrendelő igényére, annak ízlésének megfelelően alakította át. A kincsleletben a tárgyak több mint kétharmadánál jól láthatóan törekedtek arra, hogy az edényeket párba lehessen állítani (3-4., 2-7. korsók, 9-10., 20-21. csészék, 11-12. poharak, 13-14. ivócsanakok, 15-16. nyeles tálkák, 22-23. kelyhek). A 2. korsó átalakítását is ez az igény indíthatta el, viszont minden arra mutat, hogy a mintául választott 7. korsó jelenetsorát már a megrendelő kívánságának megfelelően átértelmezett, pontosított, új tartalommal és jelentéssel töltötte meg a mester. Ennek értelmezése a sas párválasztására utaló kaukázusi természeti, néprajzi, régészeti előképek, a honfoglalás kori női viselet, Nikolay Markov újabb kutatásai alapján is kizárható Ganümédész elrablásával való kapcsolat ugyanakkor Anahita, a vizek indoiráni istennőjéhez való kötődés alapján mindenképpen a párválasztás, nász témakörén belül kereshető. Már László Gyula is felhívta a figyelmet arra, hogy maga a nő és a sas násza széles körben, a szaszanida edényeken, permi bronzokon át a burját és magyar néphagyományig egyaránt elterjedt motívum. ${ }^{59}$ Azonban a konkrét esetben a kivételes értékủ kincs, a kivételes megfogalmazású ábrázolás alapján felmerül, hogy maga a bemutatott jelenet is egy hasonlóan kivételes eseményt örökített meg. Az Árpád-ház még a középkorban is szívósan továbbélő eredetmondái ${ }^{60}$ között Álmos születésénél jelenik meg a nő és a sas násza, ahogyan Anonymus Gesta Hungarorumában olvasható: Emese gyermekét 
„ $\langle\ldots\rangle$ csodás eset következtében nevezték el Álmosnak, mert teherben levő anyjának álmában isteni látomás jelent meg turulmadár képében, és mintegy reá szállva teherbe ejtette őt." ${ }^{\prime \prime I}$

Figyelembe véve az uralkodócsalád hagyományai is, az újabb kutatási eredmények alapján összességében minden korábbinál hangsúlyosabban merül fel az a lehetőség, hogy a Nagyszentmiklósi kincs 2. korsóján látható nő ábrázolása kivételes személyt és pillanatot, az Árpád-ház ősanyját jeleníti meg, az eredetmondának megfelelően a sassal való násza közben.

Az, hogy ki lehetett a megrendelő, kinek álhatott érdekében egy ilyen, akár politikai célzatú reprezentáció, arra nehéz egyértelmű választ adni, bár a lelőhely környezete és a történeti háttér ismeretében ma már elég jól leszűkíthető a kör. Mind az írás- és nyelvtörténeti adatok, ${ }^{62}$ mind Vékony Gábor olvasatai a 10. edény rovásírásáról, illetve azon véleménye, hogy a csésze Ajtony megkereszteléséhez köthető, ${ }^{63}$ arra mutat, hogy a Nagyszentmiklósi kincs a Marosvidék uráé volt. Ebben az esetben pedig a 10. csésze a hosszabb idő alatt formálódó kincsleleten belül kulcsszerepet játszik a 2. korsón látható nő jelenete és számos más edény átalakításának relatív időrendjét illetően is.

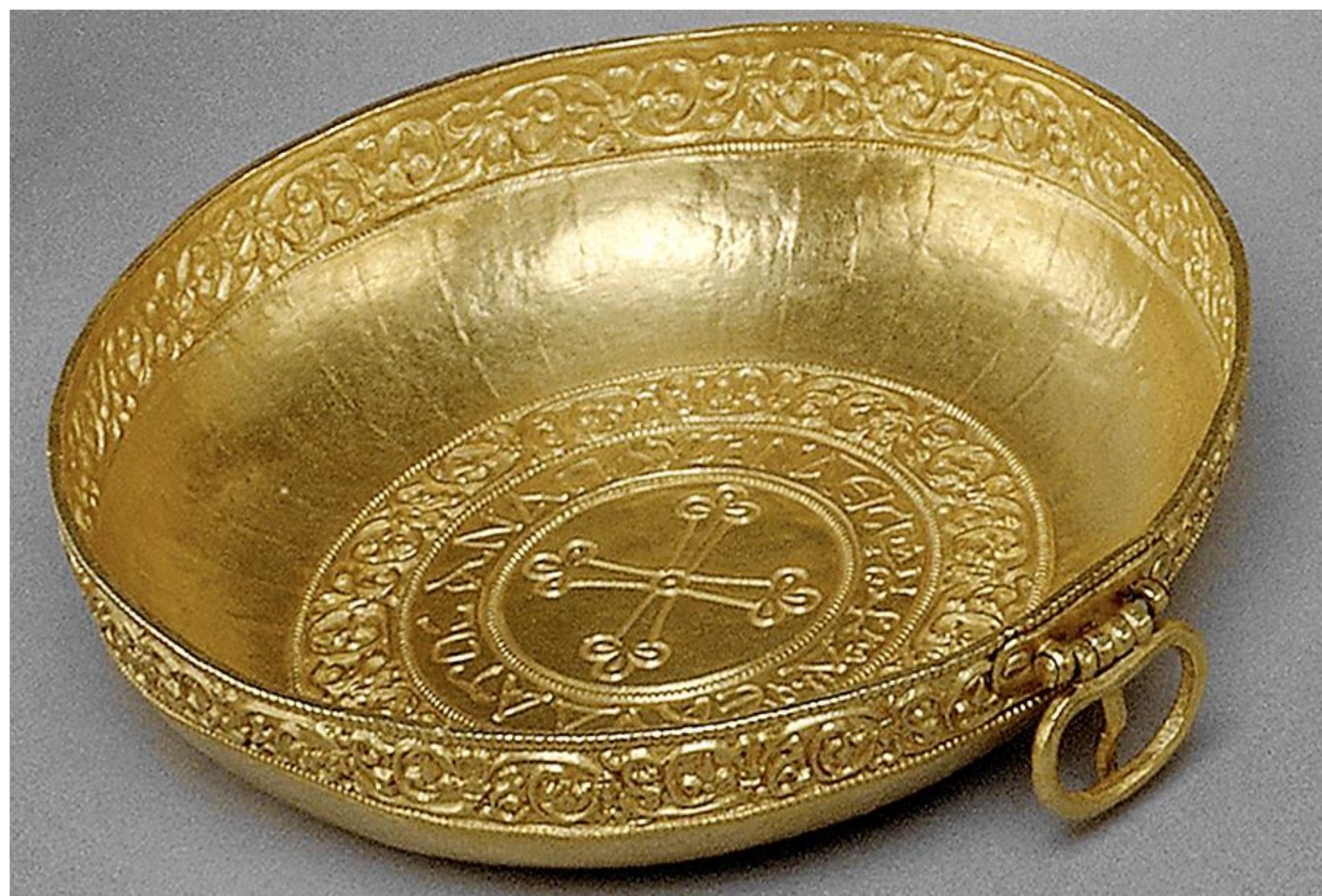

A 10. csésze, a felirata alapján Vékony Gábor szerint a Bizáncban megkeresztelt Ajtonyé volt (Fotó: Kunsthistorisches Museum Wien)

Ajtony keleti rítusú kereszténység szerint, II. Baszileiosz bizánci császár közreműködésével keresztelkedett meg Vidinben 1002-ben, s az ehhez az eseményhez kapcsolható, a görög felirat, a kereszt alapján egyértelműen keresztény elemeket tartalmazó 10. csésze így elég pontosan keltezhető. Viktor Freiberger 
és Brigit Bühler komplex archeometriai vizsgálatainak eredményei alapján, poncok alapján egy csoportba kapcsolható a 2., 7. korsó és a 8. csésze, az utóbbi kettőnél az eszközlenyomatok méretei ugyanazon szerszám használatára utalnak. ${ }^{64}$ Viszont a háromszög alakú, "nyillhegy” munkaszélű lenyomatok összekapcsolják a 8., 10., (és még a 13., 14., 15., 16., 20.) edényeket, ${ }^{65}$ ami a logikai láncolat alapján arra mutat, hogy ebben az esetben a Nagyszentmiklósi kincs 2. korsóján a nő - feltehetően az ősanya - és a sas nászának mondáját ábrázoló díszítés is legkésőbb az államalapítás első éveiben készülhetett. 


\section{Jegyzetek}

1 SZABÓ Géza: Karmos paripák. // Határtalan Régészet, 2021 (6), №1 (megjelenés alatt).

2 BálinT Csanád: A Nagyszentmiklósi kincs. Budapest: Balassi Kiadó, 2004 (Lásd még 2010).

${ }^{3}$ FEHÉR Géza: Les mouments de la culture protobulgare et leurs relations hongroises. /Archaeologia Hungarica 7.I Budapest: Magyar Nemzeti Múzeum, 1931, 35-44. O.; FeHÉR Géza: A nagyszentmiklósi kincs-rejtély megfejtésének útja. // Archaeologiai Értesítő, 1950 (77), 34-44. o.

${ }^{4}$ LÁszló Gyula-RÁcz István: A nagyszentmiklósi kincs. Budapest: Corvina, 1977.

${ }^{5}$ I. m. 41. o.

${ }^{6}$ Garam Éva-Kovács Tibor: A nagyszentmiklósi kincs-Az avarok aranya. Budapest: Helikon Kiadó, 2002.

7 BÁLINT: I. m. 531.

${ }^{8}$ Hosszú Gábor-ZeluıGer Erzsébet: Többnyelvü feliratok a Nagyszentmiklósi aranykincsen. // Magyar Nyelv, 2014 (110), 177-195. o.

${ }^{9}$ BÜHLER Birgit-FrelBeRGer Viktor: Der Goldschatz von Nagyszentmiklós / Sânnicolau Mare: Ergebnisse der goldschmiedetechnischen Untersuchungen und der Materialanalysen. In: Daim, Falko - Gschwantler - Plattner, Georg - Stadler, Peter (Hrsg.): Der Goldschatz von Sânnicolau Mare (ungarisch: Nagyszentmiklós) - The Treasure of Sânnicolau Mare (Hungarian: Nagyszentmiklós). /RGZM - Tagungen Band 25./ Manz: Verlag des Römisch-Germanischen Zentralmuseums, 2015, 9-42. o.

${ }^{10}$ Daim Falko-Gschwantler-Plattner Georg - StAdleR, Peter (Hrsg.): Der Goldschatz von Sânnicolau Mare (ungarisch: Nagyszentmiklós) - The Treasure of Sânnicolau Mare (hungarian: Nagyszentmiklós). RGZM - /Tagungen Band 25./ Manz: Verlag des Römisch-Germanischen Zentralmuseums, 2015.

${ }^{11}$ SzABó Géza: Bühler, Birgit \& Freiberger, Viktor: Der Goldschatz von Sânnicolau Mare (ungarisch: Nagyszentmiklós). // Archeometriai Múhely 2021 (XVIII), №1, 89-92. o.

12 LÁszLó Gyula-RÁcz István: I.m., 32-41. o.; Vékony Gábor: Zur Lesung der griechischen Inscchriften des Schatzes von Nagyszentmiklós.// Acta Archaeologica Hungarica, 1973 (XXV), 301. o.

${ }^{13}$ HOSSzú-ZelLiger: I. m. 187. o.

${ }^{14}$ FodoR István: Honfog/alás kori korongjaink és párhuzamaik. // Folia Archaeologica, LVI. Magyar Nemzeti Múzeum (Budapest), 2014, 147. o.

15 SZABÓ Géza: How and why do the deer and the bars appear on the belts used in the Caucasian Koban culture? // Nartamongae, 2019 (XIV), №1-2, 50-77. o.

${ }^{16}$ A Kárpát-medence bronzkori-vaskori keleti kapcsolatainak kutatása során meghatározó volt számomra, hogy 1985-ben G. I. Szmirnova segítségével az Ermitázs gyűjteményében dolgozhattam, majd Keleten számos más múzeumi anyag megismerése mellett Törökország, Irán, Grúzia és a Kaukázus, Szibéria területén terepi megfigyelésekre is lehetőségem volt.

17 HAMPEL József: A. Tanulmány a népvándorláskori müvészetről. // Archaeologiai Értesítő, 1884, №4, 24. 0.

${ }_{18}$ MAVRodinov Nikola: Le Trésor protobulgare de Nagyszentmiklós. // Archaeologia Hungarica, 1943 (XXIX), (Magyar Nemzeti Múzeum, Budapest).

${ }^{19}$ I. m. 96.

20 LÁSZLÓ-RÁCZ I. m. 184-185. o.; BÁLINT I. m. 345.0.

${ }^{21}$ MARKov Nikolay: About the Characters on Jugs № 2 and 7 from the Nagyszentmiklós Treasure. In: Doncheva-Petkova, Lyudmila - Balogh, Csilla -Türk, Attila (eds.): Avars, Bulgars and Magyars on the Middle and Lower Danube. Budapest: Archaeolingua, 2014, 93-106.

22 Uo.

${ }^{23}$ Тревер К. В.: Новые сасанидские блюда Эрмитажа. Ленинград: Государственный Эрмитаж, 1937: 14. .о.

${ }^{24}$ MARKov I. m. 96. o.

${ }^{25}$ I. m. 98. o. 
${ }^{26}$ Füzes-Frech' Miklós a 7. korsó nyakán látható növényt békatutajnak határozta meg (LÁszLó-RÁcz I. m. 183. o.).

${ }^{27}$ MARKOV I. m. 99-100. o.

${ }^{28}$ MARKOV I. m. 97. o.

${ }^{29}$ MARKov I. m. 99-100. o. (Füzes-Frech' Miklós a 7. korsó nyakán látható növényt békatutajnak határozta meg LÁSZLó-RÁCZ I. m. 183. o.)

${ }^{30}$ MAVRODINOV, I. m. 59. ábra.

${ }^{31}$ MARKOV I. m. 98. o.

32 Markov I. m. 96. o.

33 KomoRóczy Géza: „Fénylő ölednek édes örömében...” A sumer irodalom kistükre. Budapest: Európa Könyvkiadó, 1983: 151-152. o.

${ }^{34}$ SzABÓ Géza: Égi ajándék: a komló - a honfoglalás kori tarsolylemezeink díszítésérōl. // Életünk, 2018 (LVI), №8-9, 313.

${ }^{35}$ VÉkONY Gábor: A székely írás emlékei, kapcsolatai, története. Budapest: Nap Kiadó, 2004: 149. o.; Hosszú-ZeLLIGER: I. m., 187. o.

${ }^{36}$ FodoR István: Honfoglalás kori korongjaink és párhuzamaik. // Folia Archaeologica, LVI. Magyar Nemzeti Múzeum (Budapest), 2014, 147. O.; M. LEZSÁk Gabriella-NoviCHIKHIN, Andrey -GálL Erwin: The analysis of the discoid braid ornament from Andreyevskaya Shhel (Anapa, Russia) (10th century). // Acta Archaeologica Carpatica, 2018 (LIII), 143-168.

${ }^{37}$ A mai Észak-Oszét-Alánia Köztársaság őslakói többségében az inkább sztyeppei kötődésű ironok és a nyelvükben és szokásaikban is archaikusabb, az ókori Kelet felé szorosabb kapcsolatokat mutató digorok lakják (SzABó Géza: Egy iráni ősvallás nyomai a Kaukázusban és a Duna mentén. In: Hubay Péter (szerk.): Az igaz vallás. Wesley János Lelkészképző Főiskola, Budapest, 2017. 584-609; SzABó Géza: A jászok őshazájában, a digorok földjén. In: Pethő László (szerk.): Jászsági Évkönyv 2018. Jászberény: Jászsági Évkönyv Alapítvány, 2018: 123-142. o.)

${ }^{38}$ MARKov: I. M. 94. o.

${ }^{39} \mathrm{Az}$ utóbbi két évtizedben a nagyszentmiklósi és általában a honfoglalás kori leletanyag közötti lehetséges kapcsolatok elutasításának érvei között éppen az a látványos elem is szerepelt, hogy a rakamazi korongon a sas nem nőt tart a karmai között, hanem két fiókát (BÁLINT I. m.140. o.).

${ }^{40}$ Füzes-Frech' Miklós is felvetette már ezt a lehetőséget, de ő az ábrázoláshoz kapcsolódó Ganümédész-teóriára utalva Mavrodinov I. m. 94-98. o.) úgy látja, hogy az emberi lény passzív pederasztiában, a sas alakú Zeusszal passzív bestialitásban szenved (László-Rácz 1977, 184.).

${ }^{41}$ Kamilla Trever a két vadászt a Dioszkuroszokkal, a női alakot Anahita istennővel azonosította. Kérdéses azonban az is, hogy a szaszanida edény képeinek üzenetét a helyiek vajon ugyanúgy értelmezték-e. (Lásd: TPEBEP K. В.: Новые сасанидские блюда Эрмитажа. Ленинград:Государственный Эрмитаж, 1937, 13., Т. III. ; BÁLLNT I. m. 346. о.)

42 Руденко, С. И.: Горноалтайские находки и скифы. Итоги и проблемы современной науки. Москва: Наука, 1952: 107. kép.

${ }^{43}$ SzABÓ Géza: A kontinuitás változatai a regölyi grafémák tükrében. In: Fehér Bence, Ferenczi Gábor (Szerk.): Ősi írásaink. Budapest: Magyarságkutató Intézet, 2020: 227-257. o. 10. kép. A jelenet pontos hátterére, egyértelmúen megfogalmazott és jól követhető ikonográfiai elemeire, értelmezési lehetőségiről: SzABó Géza: Kaukázusi régészeti és néprajzi megfigyelések a rovásfeliratos Nagyszentmiklósi kincs értékeléséhez az újabb archaeometriai vizsgálatok tükrében. In: Fehér Bence-Ferenczi Gábor (szerk.): Ősi irásaink II.. Budapest: Magyarságkutató Intézet, 2020: 175-236. o.

${ }^{44}$ BÜHLER-FREIBERGER I. m. 80. o.

${ }^{45}$ KomORóczy Géza: Egy termékenység-szimbólum Mezopotámiában. Jegyzetek az „életfa” kérdéséhez. // Ethnographia, 1976 (LXXXVII), №4, 569-573. o.

${ }^{46}$ BÜHLER Birgit-FREIBERGER Viktor: Der Goldschatz von Nagyszentmiklós / Sânnicolau Mare: Ergebnisse der goldschmiedetechnischen Untersuchungen und der Materialanalysen. In: Daim, Falko-Gschwantler-Plattner, Georg-Stadler, Peter (Hrsg.): Der Goldschatz von Sânnicolau Mare (ungarisch: Nagyszentmiklós) - The Treasure of Sânnicolau Mare (hungarian: Nagyszentmiklós). /RGZM - Tagungen Band 25./ Manz: Verlag des Römisch-Germanischen Zentralmuseums, 2015: 942. T. 23 k., T. $157 \mathrm{f}$.

${ }^{47}$ BÁLINT I. M.165. O. 
${ }^{48}$ Uo.

${ }^{49}$ SzABÓ Géza: Égi ajándék: a komló - a honfog/alás kori tarsolylemezeink díszítéséről. // Életünk, 2018 (LVI), №8-9, 3-13. o.

${ }^{50}$ BEVILAQUA BoRSODY Béla dr.: Magyar ser főzés története múvelődéstörténeti és kézmúvességtörténeti tanulmány. Budapest: Atheneum Irodalmi és Nyomdai Részvénytársulat, 1931: 175, 581. o.

51 SzABÓ, Géza: How and why do the deer and the bars appear on the belts used in the Caucasian Koban culture? // Nartamongae, 2019 (XIV), №1-2, 50-77. o. https://doi.org/10.23671/VNC.2019.1-2.41834

${ }^{52}$ A kutatás többnyire egyetért abban, hogy a honfoglalóink ötvösei az iráni, kaukázusi, szaszanida művészet hagyományait folytató mohamedán, valamint bizánci művészetből merítettek ihletet, de csak azt vették át, amit világképük és regéik alapján értelmezhettek, saját ízlésükre formálhattak (DıENEs István: $A$ honfoglaló magyarok. Budapest: Corvina Könyvkiadó, 1972: 58. о.).

53 Нарты. Осетинский герочческий эпос. І-ІІІ. Москва: Наука, 1989-1991.

${ }^{54} \mathrm{Az}$ indás növény komlóval való azonosíthatóságát bizonyítja az egyik permi ezüsttál is, amelynek realisztikus ábrázolásán egy ibex mögött murvaleveles komlótobozok láthatók. Köszönöm Srtohmayer Ádámnak, hogy felhívta a figyelmemet erre az ábrázolásra (Lásd: nehany-permi-ezust.png (808×637) nyest.hu /Megtekintés: 2020. 02. 10./)

55 BÁlint I. m. 564. o.; Freiberger-BüHLeR I. m. 12. o.

${ }^{56}$ Korábban már Kádár Zoltán is erre a következtetésre jutott (KÁDÁR Zoltán: A nagyszentmiklósi kincs triumfális képtípusainak eredetéről. // Folia Archaeologica 13. (Magyar Nemzeti Múzeum, Budapest), 1961: 121. o.)

${ }^{57}$ BüHLER Birgit-Frelberger: I. m. 10. o., Abb. 14-15.

58 SzABÓ Géza: Karmos paripák. // Határtalan Régészet, 2021 (6), №1 (megjelenés alatt).

59 LÁsZLÓ-RÁCZ I. m. 94-96. o.

${ }^{60}$ Képes krónika. Budapest: Magyar Helikon Könyvkiadó, 1964: 84. o.

${ }^{61}$ AnOnYmus: Gesta Hungarorum (Ford.: Pais Dezső). Budapest: Magyar Helikon, 1977: 81. o.

62 Hosszú-Zeluiger: I. m. 187. o.; Következtetéseik abból a szempontból is fontosak, hogy László Gyula korábbi álláspontját, amelyben a Nagyszentmiklósi kincset az előkerülés helyéhez közel eső egykori marosvári (Csanád) székhely és utolsó csata miatt Ajtonyhoz (kb. 955-kb. 1028) kötötte, ismét a kutatás előterébe helyezték. (LÁszLóRÁCZ I. m. 187. o.).

63 VÉKONy Gábor: Zur Lesung der griechischen Inscchriften des Schatzes von Nagyszentmiklós.// Acta Archaeologica Hungarica, 1973 (XXV), 293-306. O., VÉKONY Gábor: A nagyszentmiklósi kincs történeti értékeléséhez. In: Fehér BenceFerenczi Gábor (szerk.): Ősi írásaink. Budapest: Magyarságkutató Intézet, 2020: 301. o.

${ }^{64}$ BÜHLER Birgit-Freiberger: I. m. 10., Abb. 17., 19-20. o.

65 I. m. 13., Abb. 51-55. 